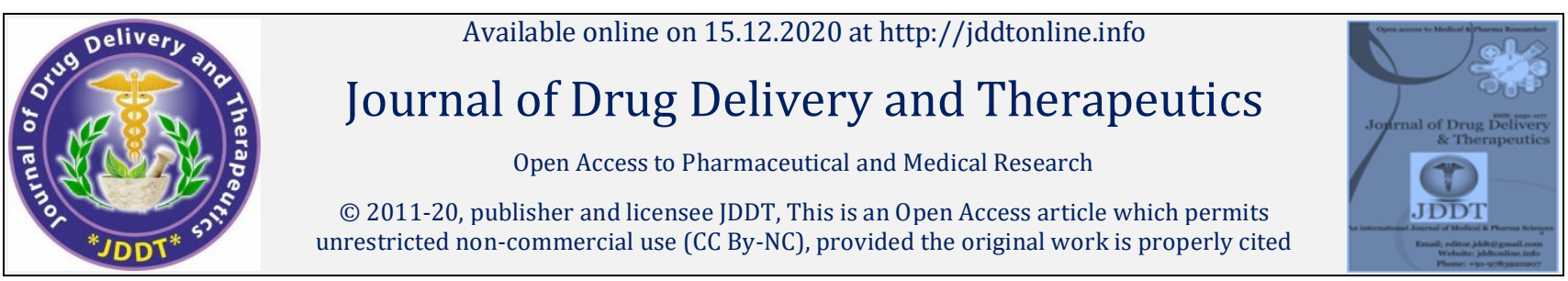

Open 8 Access

Research Paper

\title{
Cost Effective, Efficient and Stability indicating analytical method validation for Ranolazine related by Reverse Phase High Performance Liquid Chromatography in drug substances
}

\author{
Pushpendra Sharma, KLV Satyanarayana*, G. Sri Hari \\ Sri Satya Sai University of Technology \& Medical Sciences, Sehore (M.P), India-466001
}

\begin{abstract}
A simple, selective, linear, precise and accurate RP-HPLC method was developed and validated for rapid assay of Ranolazine in drug substances. Isocratic elution at a flow rate of $1.4 \mathrm{ml} / \mathrm{min}$ was employed on Hypersil BDS C18, $150 \times 4.6 \mathrm{~mm}, 5 \mu \mathrm{m}$ or Equivalent at $40^{\circ} \mathrm{C}$ column temperature. The mobile phase consisted of Mobile phase-A: Mobile phase-B (55:45) (Disodium hydrogen orthophosphate buffer with $\mathrm{pH} 7.0$ and Acetonitrile). The UV detection wavelength was at $205 \mathrm{~nm}$. Linearity was observed in concentration range of 0.07-0.82 ppm for ranolazine impurity-I and concentration range of $0.07-0.78 \mathrm{ppm}$ for ranolazine impurity-II. The retention time for Ranolazine was $7.6 \mathrm{~min}$. The method was validated for validation parameter like specificity, force degradation, linearity, accuracy, precision and robustness as per the ICH guidelines. The proposed method can be successfully applied for the estimation of Ranolazine in pharmaceutical dosage forms.
\end{abstract}

Keywords: Ranolazine, Method Validation, Drug Substances, HPLC

Article Info: Received 07 Oct 2020; $\quad$ Review Completed 18 Nov 2020; $\quad$ Accepted 29 Nov 2020; $\quad$ Available online 15 Dec 2020

Cite this article as:

Sharma P, Satyanarayana KLV, Sri Hari G, Cost Effective, Efficient and Stability indicating analytical method validation for Ranolazine related by Reverse Phase High Performance Liquid Chromatography in drug substances, Journal of Drug Delivery and Therapeutics. 2020; 10(6-s):45-54 http://dx.doi.org/10.22270/jddt.v10i6-s.4446

*Address for Correspondence:

KLV Satyanarayana, Research Scholar (PhD), Sri Satya Sai University of Technology \& Medical Sciences, Sehore (M.P), India-466001

\section{INTRODUCTION:}

Ranolazine is - (2, 6-dimethylphenyl)- 2 \{4- [2- hydroxyl -3(2-methoxy -phenoxy) propyl piprazine-1-yl $\}$ acetamideis piprazine derivative appears as white to off white crystalline powder. The drug is freely soluble in Methanol. Ranolazine is a strong base with pKa values of 13.6, Six-membered Piprazine Ring. Ranolazine melts at 122-124 degree C. Ranolazine is known to increase the QT interval on the electrocardiogram. While the mean increase in the corrected QT interval (QTc) is approximately $6 \mathrm{msec}$, about 5 percent of individuals may have QTc prolongations of $15 \mathrm{msec}$ or longer. Extended QT intervals increase the risk of sudden cardiac death (SCD). The increase was $60 \%$ in adults, independently of other known risk factors, in an analysis of the Rotterdam Study ${ }^{1-3}$.Ranolazine is not official in Pharmacopoeia. The high pressure liquid chromatography (HPLC) for Ranolazine estimation. GC method for residual solvent determination in Ranolazine drug substances. HPLC methods are widely used chromatographic methods in the analysis of Ranolazine in Formulation. LC-MS/MS, LC-MS and UHPLC use for estimation of Ranolazine in Plasma. RP HPLC method also developed for determination of concentration of Ranolazine in human serum and also for simultaneous determination of Ranolazine and Dronederone.

\section{Objective of Study:}

Literature survey revealed that methods for the determinations of ranolazine include HPLC, Gas chromatography, simultaneous spectrophotometric determination and other methods. Literature survey reveals that different assay methods like spectrophotometry, spectrofluorometry, oxidimetry and HPLC are available for the validation of ranolazine in drug substances, But none of these methods are found suitable for routine quality control studies due to the following reasons like poor sensitivity, longer run time, using costly solvent, suitable at higher concentration only, extraction procedure involved in sample preparation. Based on this, it was felt necessary to develop a validated simple, selective and sensitive HPLC method for the determination of ranolazine in drug substances. The proposed method has been demonstrated superior to the existing procedures due to its sensitivity, speed, accuracy and it is suitable for routine quality control analysis. This proposed method can be successfully employed for quality control during manufacture and for assessment of the stability of drugs in drug substances ${ }^{4-6}$. 
Table 1: Summary of Chromatographic Method of Ranolazine

\begin{tabular}{|c|c|c|c|c|}
\hline Title & Method & Mobile phase & Stationary phase & Wave Length \\
\hline $\begin{array}{l}\text { Ranolazine in bulk \& } \\
\text { marketed formulation }\end{array}$ & $\begin{array}{l}\text { HPLC \& } \\
\text { UV }\end{array}$ & $\begin{array}{l}\text { Methanol : } 0.5 \% \text { tri ethyl amine pH } 6 \\
\text { with orthophosphoric acid }(75: 25)\end{array}$ & - & 271 \\
\hline $\begin{array}{c}\text { Estimation of Ranolazine } \\
\text { HCL in Tablet Dosage } \\
\text { Form }\end{array}$ & RP-HPLC & $\begin{array}{l}\text { Buffer : Acetonitrile }(60: 40),(\mathrm{pH} \\
\text { adjust with triethylamine }\end{array}$ & Inertsil ODS C18 & $224 \mathrm{~nm}$ \\
\hline $\begin{array}{l}\text { Determination of } \\
\text { Ranolazine HCL in bulk } \\
\text { and dosage form }\end{array}$ & LC & Methanol : water $(99: 1 \%, \mathrm{~V} / \mathrm{V})$ & HiQ Sil $\mathrm{C}_{18} \mathrm{HS}$ & $273 \mathrm{~nm}$ \\
\hline $\begin{array}{c}\text { Quantitation of } \\
\text { Ranolazine in rat plasma }\end{array}$ & LC & $\begin{array}{c}\text { Acetonitrile : water : formic acid : } \\
10 \% n \text {-butylamine }(70: 30: 0.5: 0.08, \\
\text { v/v/v/v) }\end{array}$ & 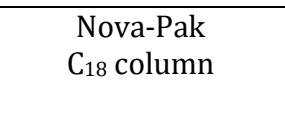 & - \\
\hline $\begin{array}{c}\text { Determination of } \\
\text { Ranolazine in human } \\
\text { plasma }\end{array}$ & HPLC & $\begin{array}{c}\text { Acetonitrile: } 0.1 \% \text { formic } \\
\text { acid(90?10) }\end{array}$ & $\begin{array}{l}\text { Agilent-ZORBAX } \\
\text { C } 18 \text { column }^{\text {and }}\end{array}$ & - \\
\hline $\begin{array}{l}\text { Estimation of Ranolazine } \\
\text { in Human Plasma }\end{array}$ & $\mathrm{LC}$ & $\begin{array}{l}\text { methanol-10mM ammonium acetate } \\
(60: 40 \mathrm{v} / \mathrm{v}, \mathrm{pH} 4.0)\end{array}$ & $\begin{array}{l}\text { Zorbax extend } \\
\text { C }_{18} \text { column }\end{array}$ & - \\
\hline $\begin{array}{l}\text { Ranolazine HCL in bulk } \\
\text { and tablet dosage form }\end{array}$ & HPTLC & $\begin{array}{l}\text { Chloroform: methanol : toluene }(5: 1 \\
\qquad: 1 \mathrm{v} / \mathrm{v} / \mathrm{v})\end{array}$ & $\begin{array}{l}\text { silica gel aluminium } \\
\text { plate } 60 \mathrm{~F}-254\end{array}$ & $273 \mathrm{~nm}$ \\
\hline $\begin{array}{l}\text { Determination of residual } \\
\text { solvents in Ranolazine }\end{array}$ & GC & - & $\begin{array}{l}\text { HP-INNOWAX } \\
\text { column }\end{array}$ & - \\
\hline
\end{tabular}

\section{METHODOLOGY:}

Materials, Chemical, Reagents, Equipment's and Column used: The details of the standards, chemicals/Reagents, Instruments and Accessories used in the method validation study are reported hereunder.

Table 2: Details of the Materials, Chemical, Reagents, Equipment's and Column used

\begin{tabular}{|l|l|c|l|}
\hline Name & Chemical name & \% Potency & Batch no \\
\hline Reference Standard & Ranolazine & 99.6 & RNZ/024/19 \\
\hline Impurity I & 6,7-dimethoxy-3,4-dihydro isoquinoline hydrochloride & 97.4 & RNZ/IMP-I/19 \\
\hline $\begin{array}{l}\text { Impurity II } \\
\text { Trans rac-3-isobutyl-9,10-dimethoxy-2,3,4,6,7,11b- } \\
\text { hexahydro-1H-pyrido[2,1-a]isoquinolin-2-ol }\end{array}$ & 95.7 & RNZ/IMP-II/19 \\
\hline $\begin{array}{l}\text { Disodium hydrogen } \\
\text { orthophosphate }\end{array}$ & NA & NA & DG0D701542 \\
\hline Acetonitrile & NA & NA & R072G20 \\
\hline Water & NA NA & NA & NA \\
\hline Ortho phosphoric acid & NA & N2045C20 \\
\hline
\end{tabular}

\section{Chromatographic Conditions:}

\begin{tabular}{|l|l|}
\hline HPLC & Waters Alliance \\
\hline Column & Hypersil BDS C18, $150 \times 4.6 \mathrm{~mm}, 5 \mu \mathrm{m}$ or Equivalent \\
\hline Flow rate & $1.4 \mathrm{ml} / \mathrm{min}$. \\
\hline Wavelength & $205 \mathrm{~nm}$ \\
\hline Column Temperature & $40^{\circ} \mathrm{C}$ \\
\hline Injection volume & $10 \mu \mathrm{l}$ \\
\hline Run time & $\begin{array}{l}20 \text { minutes for Blank, System suitability and Sample solutions and } 10 \text { minutes for } \\
\text { Diluted standard solution. }\end{array}$ \\
\hline Sample cooler temperature & $10^{\circ} \mathrm{C}$ \\
\hline Mobile phase & Mobile phase-A: Mobile phase-B (55:45) \\
\hline Rinse/wash solvent & Mixture of 20 volumes of water and 80 volumes of acetonitrile. \\
\hline Diluent & Acetonitrile \\
\hline
\end{tabular}


Preparation of Buffer solution: Weighed accurately and transferred 1.41g of disodium hydrogen orthophosphate in $1000 \mathrm{ml}$ water, mixed. Adjust $\mathrm{pH}$ to 7.0 with diluted 0 phosphoric acid solution. Filtered through $0.45 \mu$ nylon filter and degassed it.

Mobile phase A: Buffer solution.

Mobile phase B: Acetonitrile

Impurity Stock solutions:

Impurity I stock solution: Weighed accurately $5 \mathrm{mg}$ of impurity I reference standard and transferred into $100.0 \mathrm{ml}$ of clean, dry volumetric flask, added $45 \mathrm{~mL}$ of diluent and sonicated to dissolve.

Impurity II stock solution: Weighed accurately $5 \mathrm{mg}$ of impurity II reference standard and transferred into $100.0 \mathrm{ml}$ of clean, dry volumetric flask, added $45 \mathrm{ml}$ of diluent and sonicated to dissolve.

System suitability solution: Weighed accurately about $25 \mathrm{mg}$ of Ranolazine reference/working standard and transferred into $50.0 \mathrm{ml}$ of clean, dry volumetric flask, added $25 \mathrm{ml}$ of diluent and sonicated to dissolve and transferred $0.25 \mathrm{ml}$ of each Impurity I and Impurity II stock solution into it and make up to the mark with diluent.

Diluted standard solution: Weighed accurately about $25 \mathrm{mg}$ of Ranolazine reference/working standard and transferred into $50.0 \mathrm{ml}$ of clean, dry volumetric flask, added $25 \mathrm{ml}$ of diluent and sonicated to dissolve and dilute volume with diluent (Stock solution-I).Transfer $1.0 \mathrm{ml}$ of this solution into $100.0 \mathrm{ml}$ of clean, dry volumetric flask and made up to the volume with diluent (Stock solution-II). Further dilute $1.0 \mathrm{ml}$ of this solution into $10.0 \mathrm{ml}$ of clean, dry volumetric flask and made up to the volume with the diluent (Stock solutionIII).

Sample preparation: Weighed accurately about $25 \mathrm{mg}$ of sample and transferred into a $50.0 \mathrm{ml}$ of clean, dry volumetric flask, added $25 \mathrm{ml}$ of diluent and sonicated to dissolve. Allowed to equilibrate to room temperature and diluted up to the mark with diluent.

\begin{tabular}{|l|l|l|}
\hline S. No & Name of the impurity & RRT (at about) \\
\hline 1 & Impurity I & 0.30 \\
\hline 2 & Impurity II & 0.40 \\
\hline 3 & Ranolazine & 1.00 \\
\hline
\end{tabular}

System suitability Criteria: The resolution between impurity I and Impurity II peak should not be less than 1.5 from system stability solution. The \% RSD of area of Ranolazine peak for five replicate injections of diluted standard solution should not be more than 2.0 and the retention time of Ranolazine peak is about $7.5 \mathrm{~min}$.

\section{RESULT AND DISCUSSION:}

Specificity: A blank, system suitability solutions and diluted standard solution, all individual impurities at specification, impurity spiked solutions and sample of Ranolazine were prepared and injected. A system suitability criterion meets as per test method. The system suitability criteria, relative retention time of known impurities in spiked solution were observed and recorded in the below table.

Table 3: System Suitability in Specificity

\begin{tabular}{|l|l|l|l|l|l|l|l|}
\hline \multirow{2}{*}{ S. No } & \multirow{2}{*}{ Identification } & \multicolumn{2}{|l|}{ RRT } & Resolution & \multicolumn{2}{l}{ \%RSD } \\
\cline { 3 - 7 } & & Observed & $\begin{array}{l}\text { As per } \\
\text { method }\end{array}$ & Observed & $\begin{array}{l}\text { As per } \\
\text { method }\end{array}$ & Observed & As per method \\
\hline 1 & Impurity I & 0.34 & 0.30 & \multirow{2}{*}{1.93} & NLT 1.5. & $0.33 \%$ & NMT $2.0 \%$ \\
\hline 2 & Impurity II & 0.39 & 0.40 & &
\end{tabular}

Forced degradation study: Ranolazine is subjected to stress degradation at the analyte concentration using $1 \mathrm{~N}$ hydrochloric acid, $1 \mathrm{~N}$ sodium hydroxide, 5\% hydrogen peroxide and the thermal condition at $105^{\circ} \mathrm{C}$ for 24 hours to obtain required degradation. All Impurities are separated from target analyte peak and the resolution between analyte peak and closely eluting peak is well within acceptance criteria. Therefore, the method can be termed as specific and stability indicating method. Peak purity of known impurities and Ranolazine peak in the spike solution, and the degraded sample solution were observed and tabulated here under Table 4.

Table 4a: Force degradation condition of Ranolazine

\begin{tabular}{|c|c|c|c|c|c|c|c|c|}
\hline \multicolumn{4}{|c|}{ Parameters } & \multicolumn{3}{c|}{ Acid degradation } & \multicolumn{3}{c|}{ Base degradation } \\
\hline \multicolumn{3}{|c|}{ Condition } & \multicolumn{3}{|c|}{ 1N HCl_0 Hrs. } & \multicolumn{2}{c|}{ 1N NaOH_0 Hrs. } \\
\hline S.No & $\begin{array}{c}\text { Impurity } \\
\text { Name }\end{array}$ & RRT & \% Area & PA & PT & \% Area & PA & PT \\
\hline 1 & Unk & 0.16 & 13.7 & 5.46 & 0.23 & & - & - \\
\hline 2 & Unk & 0.24 & 2.47 & 4.559 & 0.274 & ND & - & - \\
\hline 3 & Unk & 0.30 & ND & - & - & ND & - & - \\
\hline 4 & Unk & 0.37 & ND & - & - & 0.05 & 5.675 & 5.842 \\
\hline 5 & Impurity-II & 0.39 & ND & - & - & ND & - & - \\
\hline 6 & Unk & 0.48 & ND & - & - & ND & - & - \\
\hline 7 & Unk & 0.53 & ND & - & - & ND & - & - \\
\hline 8 & Unk & 0.57 & ND & - & - & ND & - & - \\
\hline 9 & Unk & 0.76 & 0.04 & 9.199 & 20.756 & ND & - & - \\
\hline 10 & Unk & 1.66 & ND & - & - & ND & - & - \\
\hline 11 & Unk & 1.68 & 0.02 & 31.398 & 54.211 & ND & - & - \\
\hline 12 & Ranolazine & 1.00 & 83.76 & 1.481 & 1.66 & 99.95 & 0.745 & 0.879 \\
\hline
\end{tabular}




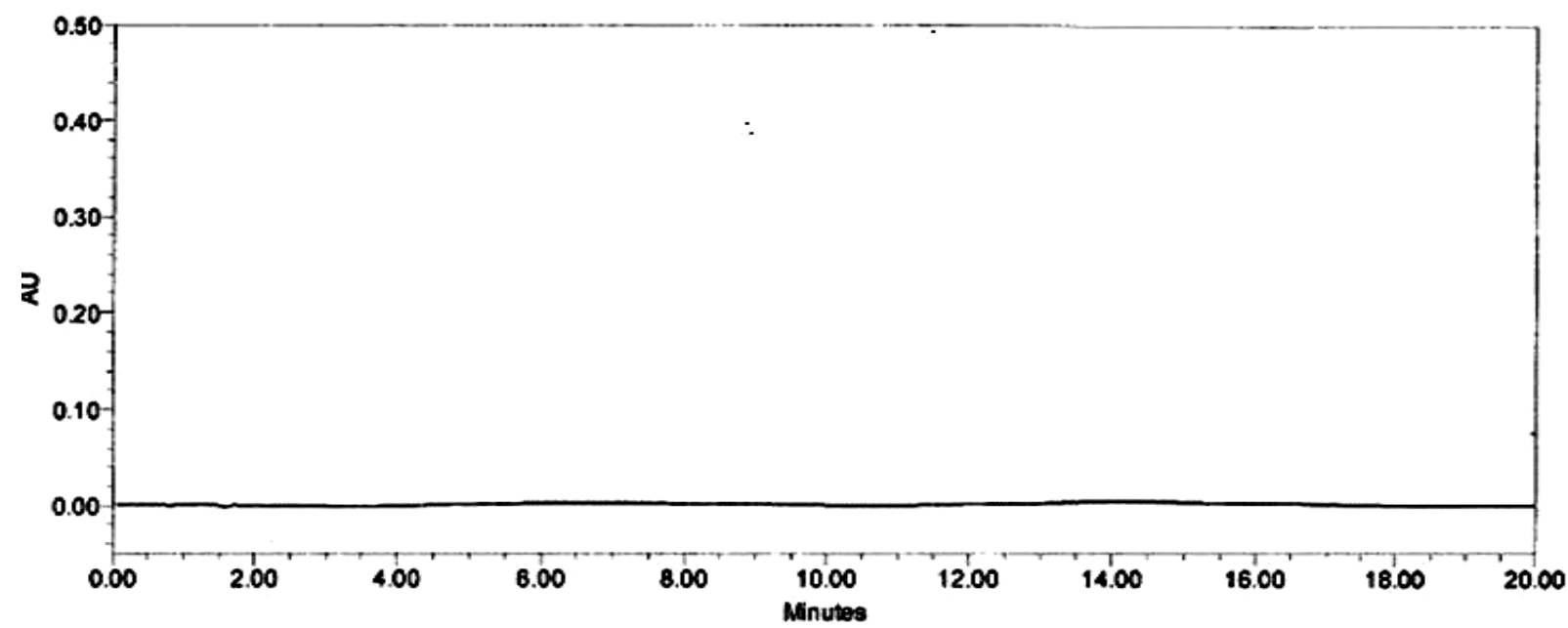

Figure 1: Reference Blank Chromatogram

Table 4b: Force degradation condition of Ranolazine

\begin{tabular}{|c|c|c|c|c|c|c|c|c|}
\hline \multicolumn{3}{|c|}{ Parameters } & \multicolumn{3}{c|}{ Peroxide degradation } & \multicolumn{3}{c|}{ Thermal degradation } \\
\hline \multicolumn{3}{|c|}{ Condition } & \multicolumn{3}{|c|}{$5 \%$ H2O2_0 Hrs. } & \multicolumn{3}{c|}{ At 105 ${ }^{\circ}$ for 24 Hrs. } \\
\hline S.No & $\begin{array}{c}\text { Impurity } \\
\text { Name }\end{array}$ & RRT & \% Area & PA & PT & \% Area & PA & PT \\
\hline 1 & Unk & 0.16 & ND & - & - & ND & - & - \\
\hline 2 & Unk & 0.24 & ND & - & - & ND & - & - \\
\hline 3 & Unk & 0.30 & 0.11 & 2.317 & 5.77 & ND & - & - \\
\hline 4 & Unk & 0.37 & ND & NA & NA & ND & - & - \\
\hline 5 & Impurity-II & 0.39 & 13.04 & 3.039 & 15.5 & ND & - & - \\
\hline 6 & Unk & 0.48 & ND & - & - & 0.41 & 5.23 & 8.29 \\
\hline 7 & Unk & 0.53 & ND & - & - & 0.06 & 11.40 & 28.38 \\
\hline 8 & Unk & 0.57 & ND & - & - & 0.05 & 20.44 & 50.46 \\
\hline 9 & Unk & 0.76 & ND & - & - & ND & - & - \\
\hline 10 & Unk & 1.66 & 0.02 & 14.319 & 28.4 & ND & - & - \\
\hline 11 & Unk & 1.68 & ND & - & - & 0.02 & 63.28 & 90.00 \\
\hline 12 & Ranolazine & 1.00 & 86.82 & 5.161 & 5.75 & 99.46 & 3.18 & 3.56 \\
\hline
\end{tabular}

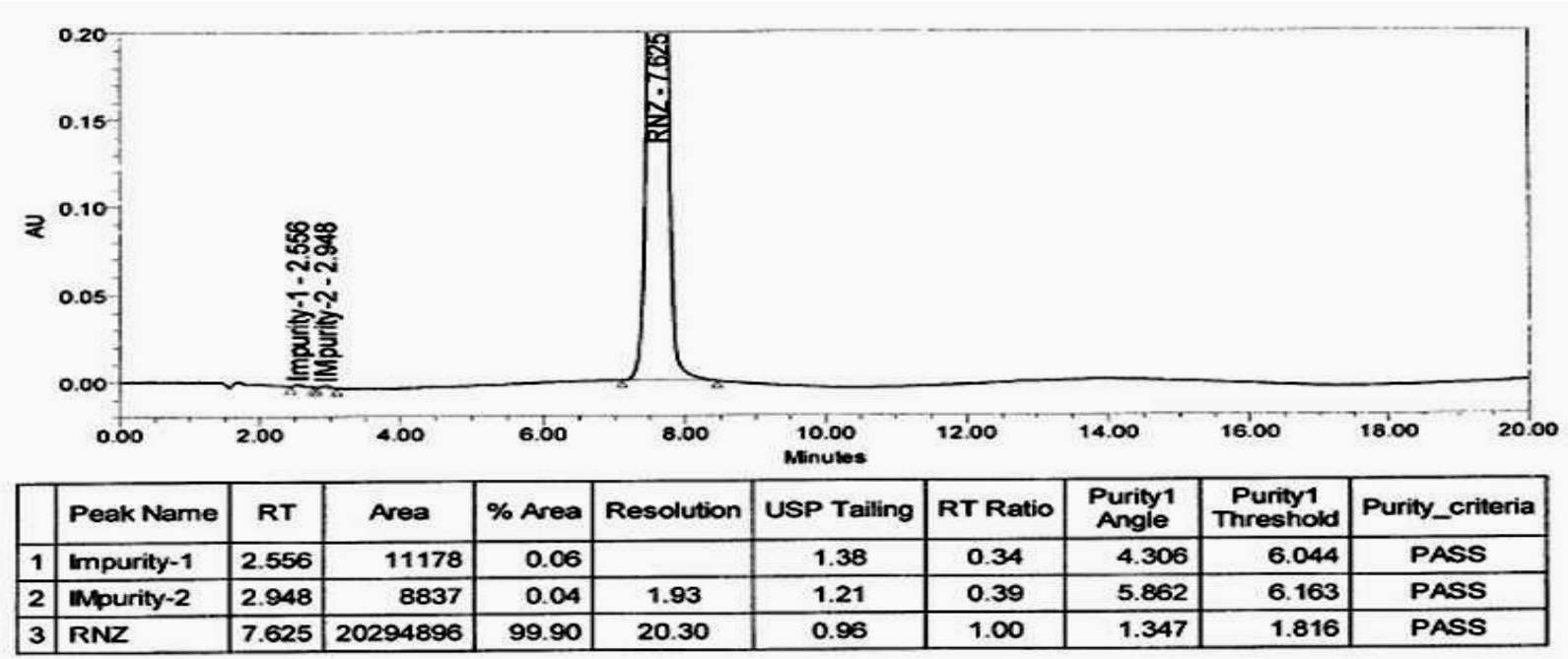

Figure 2: Reference System Suitability Chromatogram 


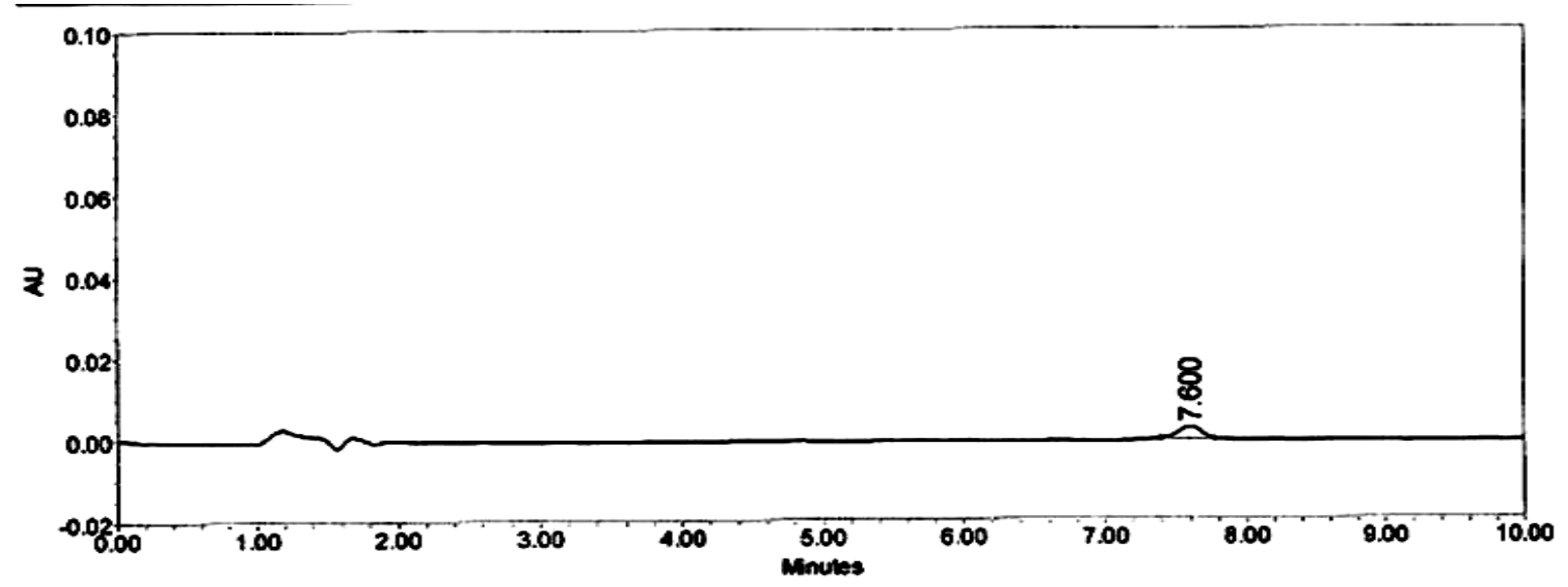

\begin{tabular}{|l|l|c|c|c|}
\hline & Peak Name & RT & Area & $\%$ Area \\
\hline 1 & RNZ & 7.600 & 30635 & 100.00 \\
\hline
\end{tabular}

Figure 3: Reference Standard Chromatogram

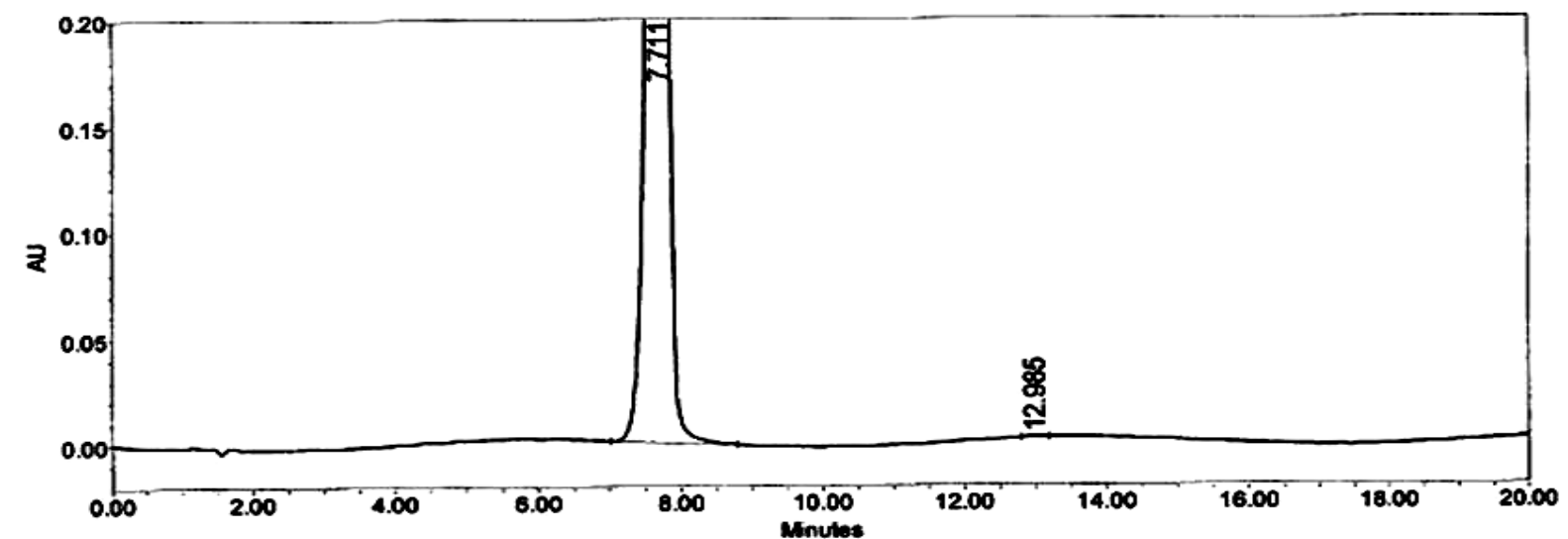

\begin{tabular}{|l|l|c|r|c|c|}
\hline & Peak Name & RT & \multicolumn{1}{c|}{ Area } & \% Area & RT Ratio \\
\hline 1 & RNZ & 7.711 & 22754180 & 99.98 & \\
\hline 2 & Peak2 & 12.985 & 4689 & 0.02 & 1.68 \\
\hline
\end{tabular}

Figure 4: Reference Control Chromatogram

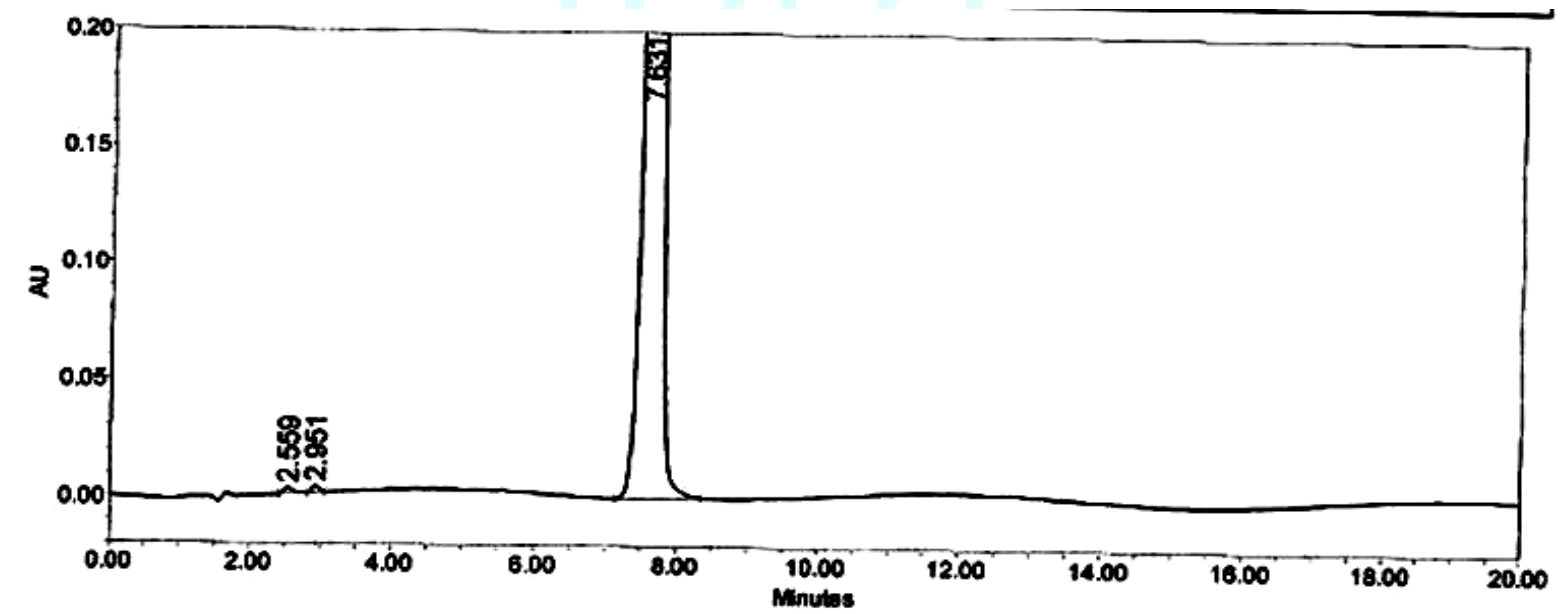

\begin{tabular}{|c|l|r|r|c|c|}
\hline & Peak Name & RT & \multicolumn{1}{c|}{ Area } & \% Area & RT Ratio \\
\hline 1 & Impurity-1 & 2.569 & 22163 & 0.11 & 0.34 \\
\hline 2 & Impurity-2 & 2.951 & 17848 & 0.09 & 0.39 \\
\hline 3 & RNZ & 7.631 & 20207256 & 99.80 & 1.00 \\
\hline
\end{tabular}

Figure 5: Reference Spike Sample Chromatogram 


\section{Limit of Detection and Limit of Quantification:}

Prediction LOD and LOQ: This experiment was carried out from the lowest concentration of each impurity to Ranolazine, to find out the quantization and detection limit for each impurity on standard deviation of response and slope method. \% RSD for each impurity at LOQ level concentration is found less than 10 (with respect to specification limit). The results obtained are well within acceptance criteria.

Table 5: Limit of Detection and Limit of Quantification

\begin{tabular}{|l|l|l|l|}
\hline Test & Imp-I & Imp-II & Ranolazine \\
\hline LOQ concentration & $0.014 \%$ & $0.0134 \%$ & $0.0172 \%$ \\
\hline LOD concentration & $0.0046 \%$ & $0.0044 \%$ & $0.0056 \%$ \\
\hline
\end{tabular}

Precision LOQ: Precision LOQ was performed by injecting six replicate injections of LOQ concentration to find the $\%$ RSD.

Table 6: Precision of Limit of Quantification

\begin{tabular}{|c|c|c|c|}
\hline S. No & Imp-I & Imp-II & Ranolazine \\
\hline 1 & 3039 & 2995 & 3336 \\
\hline 2 & 2966 & 2998 & 3508 \\
\hline 3 & 2957 & 3015 & 3228 \\
\hline 4 & 2958 & 3079 & 3297 \\
\hline 5 & 2922 & 2977 & 3422 \\
\hline 6 & 3071 & 3244 & 3381 \\
\hline Average & 2986 & 3051 & 3.04 \\
\hline \%RSD & 1.74 & 3.01 & \\
\hline
\end{tabular}

Linearity and Range: Linearity was determined at seven levels over the range of LOQ to $150 \%$ of specification limit for Impurity I, II and Ranolazine. A standard stock solution was prepared and further diluted to attain concentration at about LOQ, $50 \%, 80 \%, 100 \%, 120 \%$ and $150 \%$ of the specification limit. Each standard preparation was injected.
The area of each level was recorded and a graph of area verses slope of regression line, residual sum of squared were calculated and recorded. The linear correlation coefficient(r) for each impurity is found greater than 0.99 over the selected range. The correlation coefficient value is found well within acceptance criteria.

Table 7: Linearity and Range of Impurity I

\begin{tabular}{|l|l|l|l|}
\hline S. No & Linearity level & concentration in ppm & Area observed \\
\hline 1 & LOQ & 0.07 & 2986 \\
\hline 2 & $50 \%$ & 0.27 & 10994 \\
\hline 3 & $80 \%$ & 0.43 & 17321 \\
\hline 4 & $100 \%$ & 0.54 & 21881 \\
\hline 5 & $120 \%$ & 0.65 & 25829 \\
\hline 6 & $150 \%$ & 0.82 & 31028 \\
\hline \multicolumn{2}{|c|}{ Correlation coefficient(r) } & 0.99905 \\
\hline \multicolumn{2}{|c|}{ Slope } & 38109.615 \\
\hline
\end{tabular}

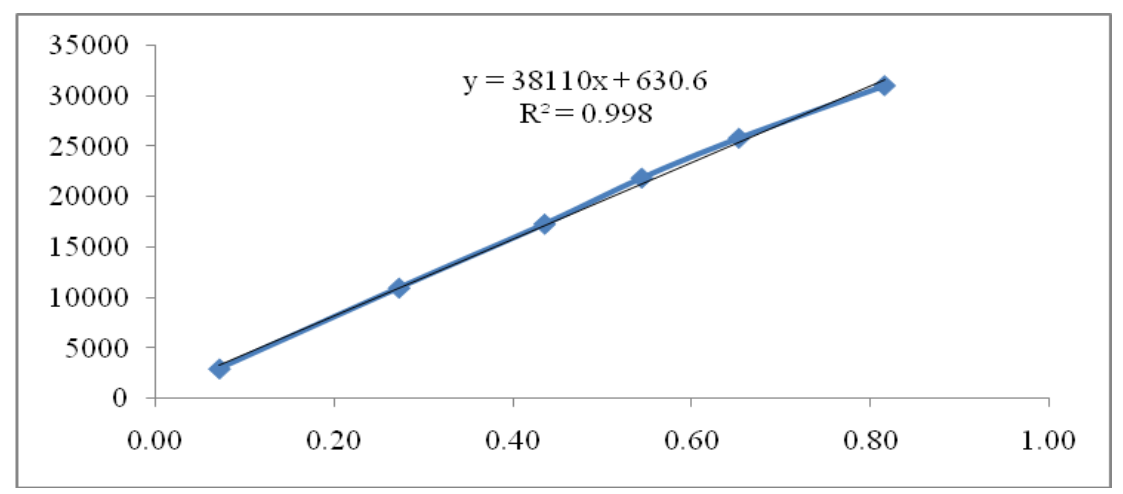

Figure 6: The graphical representation of correlation coefficient curve of Impurity I 
Table 8: Linearity and Range of Impurity II

\begin{tabular}{|l|l|l|l|}
\hline S. No & Linearity level & concentration in ppm & Area observed \\
\hline 1 & LOQ & 0.07 & 3051 \\
\hline 2 & $50 \%$ & 0.26 & 8305 \\
\hline 3 & $80 \%$ & 0.42 & 12788 \\
\hline 4 & $100 \%$ & 0.52 & 16796 \\
\hline 5 & $120 \%$ & 0.63 & 19759 \\
\hline 6 & $150 \%$ & 0.78 & 25267 \\
\hline correlation coefficient(r) & & 0.99856 \\
\hline Slope & & 31251.137 \\
\hline
\end{tabular}

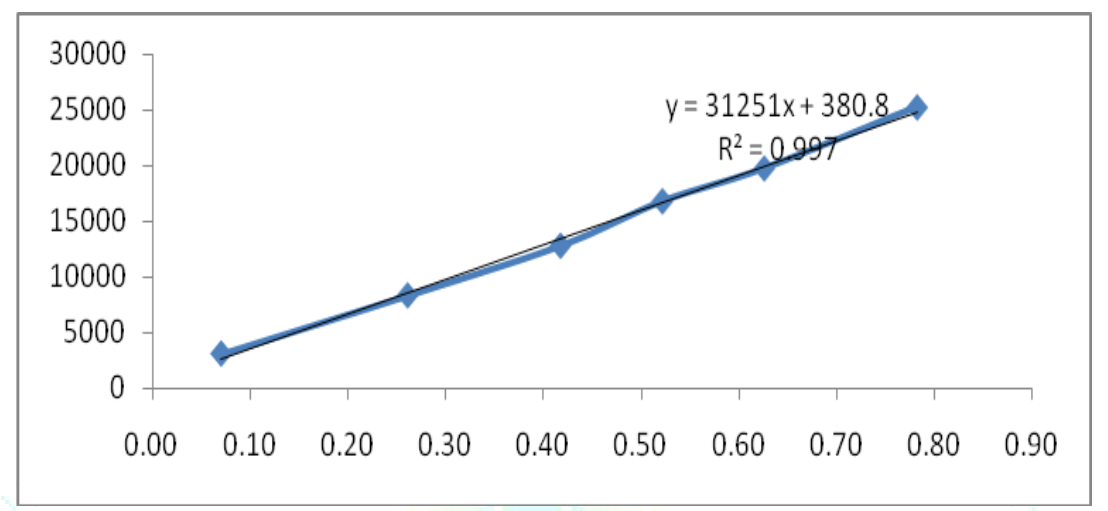

Figure 7: The graphical representation of correlation coefficient curve of Impurity II

Table 9: Linearity and Range of Ranolazine

\begin{tabular}{|l|l|l|l|}
\hline S. No & Linearity level & Concentration in ppm & Area observed \\
\hline 1 & LOQ & 0.09 & 3381 \\
\hline 2 & 50 & 0.25 & 9570 \\
\hline 3 & 80 & 0.40 & 15375 \\
\hline 4 & 100 & 0.50 & 20537 \\
\hline 5 & 120 & 0.60 & 24436 \\
\hline 6 & 150 & 0.75 & 30365 \\
\hline correlation coefficient(r) & & 0.99931 \\
\hline Slope & & 41482.935 \\
\hline
\end{tabular}

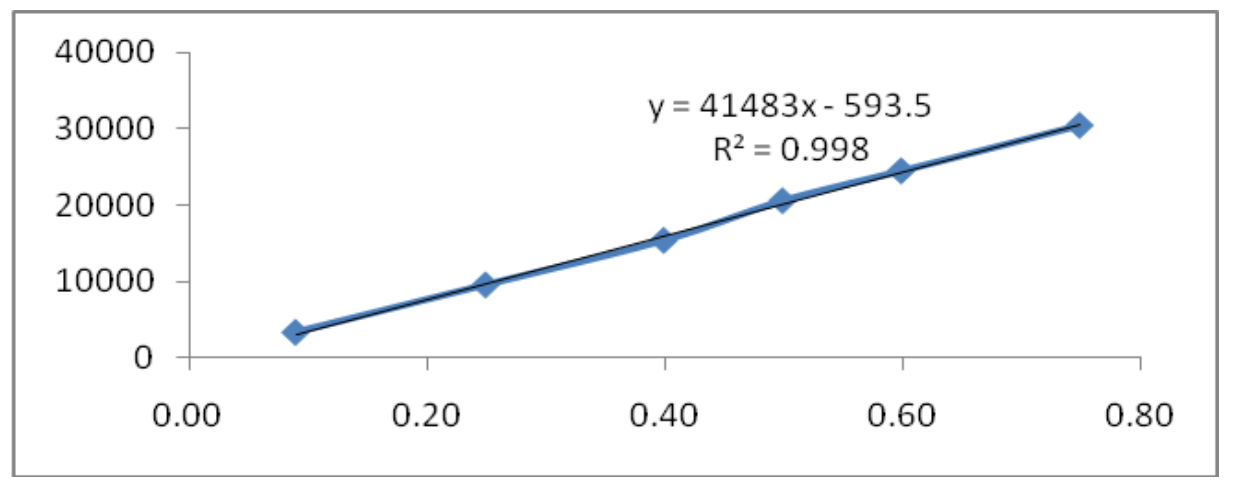

Figure 8: The graphical representation of correlation coefficient curve of ranolazine 
Table 10: Correction factor of Ranolazine \& Its Impurity (RRF)

\begin{tabular}{|l|l|l|}
\hline Name of Impurity & Slope & Correction factor (RRF) \\
\hline Impurity-I & 38109.615 & 0.92 \\
\hline Impurity-II & 31251.137 & 0.75 \\
\hline Ranolazine & 41482.935 & 1.00 \\
\hline
\end{tabular}

\section{Precision:}

Method precision: Method has been established by analyzing six sample preparations under same conditions. Six replicates of sample were prepared by one analyst and injected on the same equipment and on the same day. Calculate each known impurity Ind single maximum unknown impurity Individual (Ind) total impurities. Mean \% impurity value and \% RSD were calculated and recorded. The results obtained lies well within acceptance criteria.

Table 11: System Suitability in System Precision

\begin{tabular}{|c|c|c|c|c|c|c|c|}
\hline \multirow[b]{2}{*}{$\begin{array}{l}\text { S. } \\
\text { No }\end{array}$} & \multirow[b]{2}{*}{ Identification } & \multicolumn{2}{|l|}{ RRT } & \multicolumn{2}{|c|}{ Resolution } & \multicolumn{2}{|l|}{$\% \mathrm{RSD}$} \\
\hline & & Observed & $\begin{array}{l}\text { As per } \\
\text { method }\end{array}$ & Observed & $\begin{array}{l}\text { As per } \\
\text { method }\end{array}$ & Observed & As per method \\
\hline 1 & Impurity I & 0.34 & 0.30 & \multirow[t]{2}{*}{1.97} & \multirow[t]{2}{*}{ NLT 1.5.} & \multirow[t]{2}{*}{$1.35 \%$} & \multirow[t]{2}{*}{ NMT $2.0 \%$} \\
\hline 2 & Impurity II & 0.39 & 0.40 & & & & \\
\hline
\end{tabular}

Table 12: Result of Method Precision \& Intermediate precision study of Ranolazine

\begin{tabular}{|c|c|c|c|c|c|c|}
\hline \multirow{2}{*}{ Sample No } & \multicolumn{3}{|c|}{ Method Precision } & \multicolumn{3}{c|}{ Intermediate Precision } \\
\cline { 2 - 6 } & Imp I & Imp II & Total impurities & Imp I & Imp II & Total impurities \\
\hline 1 & 0.091 & 0.093 & 0.184 & 0.091 & 0.094 & 0.183 \\
\hline 2 & 0.090 & 0.092 & 0.182 & 0.090 & 0.091 & 0.181 \\
\hline 3 & 0.093 & 0.092 & 0.186 & 0.093 & 0.092 & 0.186 \\
\hline 4 & 0.088 & 0.088 & 0.176 & 0.088 & 0.087 & 0.175 \\
\hline 5 & 0.089 & 0.090 & 0.179 & 0.089 & 0.090 & 0.179 \\
\hline 6 & 0.095 & 0.096 & 0.191 & 0.095 & 0.093 & 0.191 \\
\hline Mean & $\mathbf{0 . 0 9 1}$ & $\mathbf{0 . 0 9 2}$ & $\mathbf{0 . 1 8 3}$ & $\mathbf{0 . 0 9 1}$ & $\mathbf{0 . 0 9 2}$ & $\mathbf{0 . 1 8 2}$ \\
\hline RSD \% & $\mathbf{2 . 8 6 3}$ & $\mathbf{2 . 8 7 5}$ & $\mathbf{2 . 7 9 2}$ & $\mathbf{2 . 6 1 6}$ & $\mathbf{2 . 5 0 7}$ & $\mathbf{2 . 7 9 3}$ \\
\hline
\end{tabular}

Accuracy (Recovery): Accuracy was performed by spiked all known impurities in the test preparation at 50\%, 100\% and $150 \%$ of specification limit. Samples were prepared in triplicate at each level and each preparation is injected separately. The average recovery of known impurities at each level is found between $80 \%$ to $120 \%$.The $\%$ individual recovery and \% mean recovery for each level was calculated and recorded in the below tables.

Table 13a: Accuracy for Impurity I

\begin{tabular}{|c|c|c|c|c|c|c|c|}
\hline Levels & $\begin{array}{l}\text { Area of } \\
\text { IMP-I }\end{array}$ & Conc.mg/ml & ppm & $\%$ of IMP-I Added & $\begin{array}{l}\% \\
\text { Corrected }\end{array}$ & $\%$ Recovery & \% Avg.Recovery \\
\hline \multirow{3}{*}{$50 \%$} & 10286 & 0.00024 & 0.237 & 0.047 & 0.043 & 91.76 & \multirow{3}{*}{93.38} \\
\hline & 10543 & 0.00024 & 0.237 & 0.047 & 0.045 & 94.02 & \\
\hline & 10607 & 0.00024 & 0.237 & 0.047 & 0.045 & 94.36 & \\
\hline \multirow{3}{*}{$100 \%$} & 21589 & 0.00047 & 0.473 & 0.095 & 0.091 & 96.18 & \multirow{3}{*}{95.92} \\
\hline & 21269 & 0.00047 & 0.473 & 0.095 & 0.090 & 94.95 & \\
\hline & 21682 & 0.00047 & 0.473 & 0.095 & 0.091 & 96.64 & \\
\hline \multirow{3}{*}{$150 \%$} & 30214 & 0.00071 & 0.710 & 0.142 & 0.128 & 90.10 & \multirow{3}{*}{86.71} \\
\hline & 27676 & 0.00071 & 0.710 & 0.142 & 0.120 & 84.42 & \\
\hline & 28206 & 0.00071 & 0.710 & 0.142 & 0.122 & 85.62 & \\
\hline
\end{tabular}


Table 13b: Accuracy for Impurity II

\begin{tabular}{|c|c|c|c|c|c|c|c|}
\hline Level & $\begin{array}{l}\text { Area of } \\
\text { IMP-I }\end{array}$ & Conc.mg/ml & ppm & $\%$ of IMP-I Added & $\%$ Corrected & \% Recovery & \% Avg.Recovery \\
\hline \multirow{3}{*}{$50 \%$} & 8800 & 0.00024 & 0.243 & 0.049 & 0.046 & 93.95 & \multirow{3}{*}{95.78} \\
\hline & 8856 & 0.00024 & 0.243 & 0.049 & 0.046 & 94.51 & \\
\hline & 9288 & 0.00024 & 0.243 & 0.049 & 0.048 & 98.88 & \\
\hline \multirow{3}{*}{$100 \%$} & 18759 & 0.00049 & 0.485 & 0.097 & 0.097 & 100.02 & \multirow{3}{*}{98.01} \\
\hline & 17679 & 0.00049 & 0.485 & 0.097 & 0.092 & 94.45 & \\
\hline & 18666 & 0.00049 & 0.485 & 0.097 & 0.097 & 99.56 & \\
\hline \multirow{3}{*}{$150 \%$} & 30995 & 0.00073 & 0.728 & 0.146 & 0.161 & 110.61 & \multirow{3}{*}{105.13} \\
\hline & 28996 & 0.00073 & 0.728 & 0.146 & 0.151 & 103.64 & \\
\hline & 28423 & 0.00073 & 0.728 & 0.146 & 0.147 & 101.15 & \\
\hline
\end{tabular}

Solution stability at $25^{\circ} \mathrm{C}$ : The blank, system suitability and Test solution and initial \% impurity was determined. As per method sample preparation was stored at $25^{\circ} \mathrm{C}$ for different time interval like $0 \mathrm{hrs}$. and $24 \mathrm{hrs}$. All the known impurities are found stable up to 24 hours in the spiked sample (SST) and as such sample. The $\%$ of impurity-II is found increasing significantly after $24 \mathrm{hrs}$.in as such sample. The solution is found stable up to $24 \mathrm{hrs}$.

Table 14: Solution stability of Ranolazine

\begin{tabular}{|l|l|c|c|c|c|}
\hline Sample Name & Time & Impurity-I & Impurity-II & $\begin{array}{l}\text { Unknown } \\
\text { impurity }\end{array}$ & Total impurities \\
\hline \multirow{2}{*}{$\begin{array}{l}\text { System suitability } \\
\text { solution }\end{array}$} & RRT & 0.34 & 0.39 & 1.67 & - \\
\cline { 2 - 6 } & Initial (0 hrs) & 0.05 & 0.05 & ND & 0.10 \\
\cline { 2 - 6 } & 24 hrs. & 0.05 & 0.05 & ND & 0.10 \\
\hline As such sample & Initial (0 hrs.) & ND & ND & 0.03 & 0.03 \\
\cline { 2 - 6 } & 24 hrs. & ND & 0.01 & 0.03 \\
\hline
\end{tabular}

Robustness: The robustness of the method was established by making deliberate minor variations in the following method parameters. Change in flow rate of Mobile phase to $1.3 \mathrm{ml} / \mathrm{min}$ and $1.4 \mathrm{ml} / \mathrm{min}$ Change in column oven temperature to $39^{\circ} \mathrm{C}$ to $41^{\circ} \mathrm{C}$. A system suitability criterion meets as per test method. Relative retention time of each impurity is found as per test method. All the impurities are well separated from each other and from Ranolazine peak in the changed conditions. The effect of changes was observed on system suitability values and recorded in the below tables.

Table 15: Table of Robustness Study parameter in Ranolazine

\begin{tabular}{|c|c|c|c|c|}
\hline Parameter & Condition & Impurity I & Impurity II & $\begin{array}{l}\text { Total } \\
\text { impurities }\end{array}$ \\
\hline \multicolumn{5}{|l|}{ Change in Column temperature } \\
\hline Normal condition* & $40^{\circ} \mathrm{C}$ & 0.091 & 0.092 & 0.183 \\
\hline Deliberate condition & $39^{\circ} \mathrm{C}$ & 0.084 & 0.103 & 0.187 \\
\hline Difference from normal condition & $-1^{\circ} \mathrm{C}$ & 0.007 & -0.011 & -0.004 \\
\hline \multicolumn{5}{|l|}{ Change in Column temperature } \\
\hline Deliberate condition & $41^{\circ} \mathrm{C}$ & 0.082 & 0.097 & 0.179 \\
\hline Difference from normal condition & $+1^{\circ} \mathrm{C}$ & 0.009 & -0.005 & 0.004 \\
\hline \multicolumn{5}{|l|}{ Change in Flow rate } \\
\hline Normal condition* & $1.4 \mathrm{ml} / \mathrm{min}$ & 0.091 & 0.092 & 0.183 \\
\hline Deliberate condition & $1.3 \mathrm{ml} / \mathrm{min}$ & 0.081 & 0.104 & 0.185 \\
\hline Difference from normal condition & $-0.1 \mathrm{ml} / \mathrm{min}$ & 0.01 & -0.012 & -0.002 \\
\hline \multicolumn{5}{|l|}{ Change in Column temperature } \\
\hline Deliberate condition & $1.5 \mathrm{ml} / \mathrm{min}$ & 0.072 & 0.096 & 0.168 \\
\hline Difference from normal condition & $+0.1 \mathrm{ml} / \mathrm{min}$ & 0.019 & -0.004 & 0.015 \\
\hline
\end{tabular}


Table 16: System suitability criteria in Robustness

\begin{tabular}{|l|c|c|c|c|c|}
\hline \multirow{2}{*}{ Parameter } & Condition & Resolution & \multirow{2}{*}{ \%RSD } & \multicolumn{2}{|c|}{ RRT } \\
\cline { 4 - 6 } & & & & \\
\hline Change in Column temperature & & & & \\
\hline
\end{tabular}

* The initial data taken from method precision.

\section{CONCLUSION:}

A validated RP-HPLC method has been developed for the determination of related substance in Ranolazine drug substances. The proposed method is simple, rapid, accurate, precise and specific. Its chromatographic run time of $6 \mathrm{~min}$ allows the analysis of a large number of samples in short period of time. Therefore, it is suitable for the routine analysis of Ranolazine in pharmaceutical dosage form.

\section{ACKNOWLEDGEMENT:}

Authors would like to thanks the department of chemistry, SSSUTMS, Sehore Madhya Pradesh India for giving us an opportunity to carry out validation \& provide necessary facilities in Laboratories.

\section{REFERENCES:}

1. Patel RC, Rathod DK, Patel PR, Patel VS. Estimation of Ranolazine Hydrochloride by Spectrophotometric and RP-HPLC in tablet dosage forms. International Journal of Pharmaceutical and Appiled Sciences. 2010; 2:79-83.

2. FDA Approves New Treatment for Chest Pain. FDA News. 200601-31. Retrieved 2007-02-04.

3. Sharma T, Moitra SK, Si SC, Sankar DG. Stability indicating LC method for the determination of Ranolazine Hydrochloride in the bulk drug and in pharmaceutical dosage form. International Journal of Pharmacy and Pharmaceutical Sciences. 2011; 4:327332.

4. Lei T, Juanjuan J, Yiling H, Lu H, Hong L, Yishi L. Sensitive quantification of Ranolazine in human plasma by liquid chromatography-tandem mass spectrometry with positive electrospray ionization. Journal of Chromatography B. 2007; 846:346-350.

5. Satyanarayana PVV, Murali M. Development and validation of LC Method for the estimation of Tretinoin in pharmaceutical dosage form, International Journal of Research and Reviews in Pharmacy and Applied Sciences.2011; 1:13-19.

6. International Conference on Harmonization, ICH harmonized tripartite guideline validation of analytical procedures: text and methodology Q2 (R1) ICH, Geneva, 2005. 